\title{
Obesitas: Pentingkah Memperhatikan Konsumsi Makanan di Akhir Pekan?
}

\author{
Obesity: Is It Important to Concern about Food Intake in The Weekend?
}

Syafira Kandinasti*1, Farapti $^{2}$

\begin{abstract}
ABSTRAK
Latar belakang: Prevalensi obesitas pada semua kelompok umur meningkat di hampir seluruh negara di dunia. Studi epidemiologi menunjukkan bahwa asupan energi dan zat gizi makro diakhir pekan meningkat dibandingkan hari biasa dan berperan pada kejadian obesitas.

Tujuan: Tujuan dari literatur review ini adalah untuk menganalisis perbedaan asupan energi dan zat gizi makro diakhir pekan dibandingkan hari biasa dan bagaimana kontribusinya terhadap obesitas.

Ulasan: Telaah beberapa artikel menunjukan bahwa rata-rata asupan energi dan zat gizi makro mengalami peningkatan saat akhir pekan dibandingkan hari biasa. Konsumsi unhealthy food di akhir pekan seperti makanan dan minuman dengan kandungan tinggi gula, tinggi lemak, dan alkohol tampaknya menyebabkan peningkatan kalori dan berperan pada insiden obesitas.

Kesimpulan: Diperlukan upaya pencegahan obesitas melalui promosi kesehatan masyarakat dengan memperhatikan asupan makanan saat hari libur baik dari segi kuantitas maupun kualitasnya.
\end{abstract}

Kata kunci: asupan makanan, akhir pekan, hari biasa, obesitas

\begin{abstract}
Background: The prevalence of obesity in all age groups has increased in some countries. Epidemiological studies indicated that the intake of energy and macronutrient over the weekend were increasing rather than on weekdays and contributed to the incidence of obesity.

Objectives: The aim of this literature review is to analyze the different between intake of energy and macronutrients in weekdays compared to weekend and how it contributes to obesity.

Discussion: Showed that energy and macronutrient intake were increasing over the weekend than on weekdays. Consumption of unhealthy food on weekend such as foods and beverages with high sugar, high fat and alcohol increase the energy and play a role in the incidence of obesity.

Conclusion: The health promotion concerning food intake on weekdays and weekend both in terms of quantity and quality is needed for obesity prevention.
\end{abstract}

Keywords: food intake, weekend, weekday, obesity

\footnotetext{
*Koresponden:

kandinasti@gmail.com

1,2Program Studi Gizi, Fakultas Kesehatan Masyarakat,

Universitas Airlangga, Surabaya, Jawa Timur, Indonesia
} 


\section{PENDAHULUAN}

Obesitas adalah suatu kondisi dimana terjadi akumulasi lemak yang berlebih atau abnormal yang dapat menimbulkan efek buruk bagi kesehatan. Organisasi Kesehatan Dunia (WHO) pada tahun 2014 mencatat bahwa 1.9 miliar orang dewasa mengalami kelebihan berat badan dengan prevalensi 39\% mengalami overweight dan $13 \%$ mengalami obesitas, serta 41 juta anak balita mengalami overweight dan obesitas. Obesitas paling banyak terjadi pada wanita dengan prevalensi $15 \%$ dan laki-laki 11\%. ${ }^{1}$ Data NHANES tahun 2009-2010 dan 2016-2016 di Amerika Serikat memperlihatkan terjadinya peningkatan prevalensi obesitas pada orang dewasa dari $35.7 \%$ menjadi $39.8 \%$ serta pada anak dan remaja dari $16.9 \%$ menjadi 18.5\%. ${ }^{2,3}$ Di Indonesia berdasarkan data Riset Kesehatan Dasar (Riskedas) tahun 2007 dan 2013 dapat diketahui bahwa terjadi peningkatan prevalensi orang dewasa yang mengalami obesitas dari $13.7 \%$ menjadi $15.4 \% .{ }^{4,5}$

Obesitas merupakan salah satu faktor penyebab kematian secara global. Sekitar 3.4 juta orang dewasa meninggal setiap tahunnya karena obesitas atau overweight. Peningkatan indeks massa tubuh dapat menjadi faktor resiko terhadap penyakit tidak menular. Obesitas dan overweight berkaitan dengan $44 \%$ dari permasalahan diabetes, $23 \%$ dari penyakit jantung iskemik dan $7-41 \%$ dari permasalahan kanker. $^{1}$ Obesitas juga berpengaruh terhadap kepercayaan diri seseorang. Studi sistematik review menunjukkan orang yang mengalami obesitas memiliki rasa ketidakpuasan terhadap tubuh lebih tinggi dibandingkan dengan mereka dengan status gizi normal. ${ }^{6}$ Obesitas pada usia remaja dapat berdampak pada terjadinya masalah sindroma metabolik, kesehatan mental, dan penurunan prestasi akademik..$^{7-9}$

Pola makan yang termasuk gaya hidup merupakan penyebab utama terjadinya sindroma metabolik. Resiko sindroma metabolik meningkat dengan meningkatnya kebiasaan pola makan terhadap beberapa jenis makanan seperti daging, susu dan produk olahannya, serta sereal olahan. Semakin banyak asupan makan, terutama kolesterol, total kalori, lemak dan karbohidrat maka semakin meningkat kejadian sindroma metabolik. ${ }^{10}$

Obesitas dapat terjadi apabila asupan energi melebihi pengeluaran energi yang mengakibatkan ketidak seimbangan energi dan berdampak pada peningkatan berat badan, dimana $60 \%$ hingga $80 \%$ biasanya berupa massa lemak tubuh. Selain itu faktor genetik dan lingkungan mempengaruhi berat badan melalui keseimbangan energi. ${ }^{11}$ Pada proses metabolisme energi, diperlukan peran asupan makanan khususnya zat gizi makro. zat gizi makro yang terdiri dari karbohidrat, lemak, protein berperan penyumbang kalori dan makanan tinggi kalori terbukti menjadi salah satu penyebab obesitas. Beberapa hasil penelitian menunjukkan terjadi peningkatan asupan zat gizi makro di akhir pekan dibandingkan hari biasa dan hal tersebut berkontribusi terhadap peningkatan berat badan. Penelitian longitudinal Racette et al pada 48 orang dewasa usia 50-60 tahun menunjukkan adanya peningkatan asupan energi pada akhir pekan dibandingkan hari biasa. Selain itu juga terjadi peningkatan berat badan $0.077 \mathrm{~kg}$ setiap minggu, meskipun kecil namun bisa berdampak pada kenaikan $4 \mathrm{~kg}$ dalam satu tahun jika pola serupa berkelanjutan. ${ }^{12}$ Penelitian cross sectional pada 80 subjek usia 25-62 tahun dengan mengukur berat badan selama 7 hari berturutturut menunjukkan pola perubahan berat badan yang mulai mengalami peningkatan pada hari sabtu dan kembali menurun mulai hari selasa. ${ }^{13}$

Akhir pekan biasanya dimanfaatkan oleh sebagian besar orang untuk refreshing dari tugas atau pekerjaan, dengan menghabiskan waktu bersama keluarga atau teman dengan mengunjungi tempat yang dianggap menarik seperti mall, cafe, hingga bioskop. Pada akhir pekan restoran dan outlet makanan lebih mendapatkan banyak mendapatkan pengunjung dibandingkan dengan hari biasa. Hal tersebut menunjukkan antusias masyarakat untuk makan di luar rumah terutama saat akhir pekan. ${ }^{14}$ Berdasarkan studi longitudinal Jahns et al pada wanita dewasa menyatakan dibandingkan hari biasa, saat akhir pekan prevalensi makan malam di restoran fast food meningkat dari $13.2 \%$ menjadi $18.7 \%{ }^{15}$ Makanan yang 
ditawarkan di restoran dan fast food yang dalam satu kali makan umumnya memiliki porsi dan kalori sering melebihi dari kebutuhan energi harian seseorang. ${ }^{16}$ Makanan yang dijual di luar rumah mengandung lebih banyak kalori per sekali makan, kandungan total lemak yang lebih tinggi, kandungan serat, kalsium dan besi yang rendah, serta lebih banyak kandungan narium dibandingkan dengan makanan yang disiapkan dirumah. ${ }^{17}$ Tingginya konsumsi makanan dan minuman yang dibeli di luar rumah khususnya saat akhir pekan, menjadi hal yang sangat penting untuk memperhatikan asupan makanan saat akhir pekan sebagai pencegahan terhadap obesitas. Studi literatur ini bertujuan menganalisis apakah terdapat perbedaan asupan makanan khususnya kalori dan zat gizi makro (karbohidrat, protein, lemak) saat hari biasa dan akhir pekan dan bagaimana pengaruhnya terhadap peningkatan berat badan.

\section{DISKUSI}

\section{Asupan Makan dan Faktor Resiko Obesitas}

Obesitas dan overweight merupakan permasalahan kesehatan yang serius dan banyak terjadi di seluruh dunia. Obesitas bukan hanya menjadi permasalahan pada orang dewasa tetapi juga pada semua kelompok usia. ${ }^{18}$ Obesitas terjadi disebabkan oleh ketidakseimbangan antara jumlah kalori yang masuk dengan kalori yang dikeluarkan. Faktor penyebab obesitas diantaranya yaitu kondisi psikologis yang dipengaruhi oleh faktor stress dan lama tidur, penurunan aktifitas fisik dan peningkatan sedentary lifestyle, faktor genetik, asupan makan yang tinggi kalori dan lemak, perubahan model transportasi, dan meningkatnya urbanisasi. ${ }^{1,16}$

Asupan makan sebagai salah satu faktor resiko obesitas telah dibuktikan melalui hasilhasil penelitian. Aspek makanan yang meliputi rasa, variasi, harga, porsi, dan fasilitas sosial dapat menyebabkan pemilihan makanan yang tinggi kalori. Seseorang akan mengonsumsi makanan dalam jumlah yang lebih banyak ketika ada orang lain yang bergabung saat makan bersama. Dibandingkan alasan kesehatan, rasa dari makanan dianggap sebagai salah satu alasan untuk memilih makanan dan mengonsumsi semua jenis makanan yang tersedia. ${ }^{19}$ Rasa merupakan elemen yang dapat berpengaruh untuk membangkitkan rasa ingin makan. Berbagai variasi makan yang dijual dan dapat diperoleh setiap waktu dengan harga yang rasional dapat berkontribusi terhadap variasi makan yang tinggi kalori. Keberagaman makanan yang tersedia diwaktu makan juga mempengaruhi terbentuknya pola makan individu. Orang akan cenderung mengonsumsi makanan berlebih ketika banyak makanan yang tersedia dibandingkan jika hanya ada satu jenis makanan saja yang tersedia. Makan yang berlebih juga dapat disebabkan oleh porsi makan yang besar dibandingkan biasanya. ${ }^{16}$

Anak pada keluarga yang setiap minggu makan di luar rumah sekali atau lebih cenderung lebih banyak mengkonsumsi minuman manis dan memiliki prevalensi status BMI overweight hampir 5\% lebih tinggi dibandingkan dengan anak yang berasal dari keluarga yang jarang makan di luar rumah. ${ }^{17}$ Pada usia anak-anak terjadi peningkatan asupan energi 20-30 kkal di akhir pekan. Hal ini disebebkan oleh meningkatnya persentasi energi dari lemak, menurunnya konsumsi buah dan sayur di akhir pekan, dan meningkatnya konsumsi gula dari minuman dan makanan manis. ${ }^{19}$

Asupan energi remaja di Amerika 20 kkal lebih tinggi saat akhir pekan yang disebabkan oleh peningkatan asupan lemak dan frekuensi makan malam karena remaja lebih sering melewatkan sarapan dan makan siang. Selain itu konsumsi makanan dan minuman padat energi di akhir pekan juga lebih tinggi yang ditandai dengan meningkatnya konsumsi kue, biscuit, dan minuman manis, serta asupan buah dan sayur yang signifikan lebih rendah. ${ }^{19}$ Berdasarkan penelitian Post et al pada remaja usia SMA menyatakan peningkatan asupan energi, karbohidrat, protein dan lemak di akhir pekan berdampak pada peningkatan rata-rata berat badan remaja dan berdasarkan pengukuran skinfold persentasi lemak tubuh remaja putri meningkat dari $23 \%$ menjadi $28 \%$ dan pada laki-laki dari $15 \%$ menjadi $17 \%{ }^{20}$

Saat akhir pekan, konsumsi buah-buahan pada orang dewasa menurun dibandingkan dengan hari biasa dan orang dewasa lebih suka mengganti konsumsi air putih dengan anggur, sedangkan konsumsi minuman panas seperti 
teh dan kopi berkurang. Di akhir pekan orang dewasa lebih suka meninggalkan sarapan dan frekuensi makan diluar rumah seperti di restoran dan bar meningkat 2 kali lipat. ${ }^{19}$ Jumlah orang dewasa dengan status gizi obesitas tingkat berat pada keluarga yang mengunjungi restoran sekali atau lebih dalam seminggu, dua kali lebih banyak dibandingkan keluarga yang jarang. ${ }^{17}$ Lebih dari $40 \%$ energi dari lemak didapatkan dari makanan yang dijual diluar rumah. Konsumsi jajanan seperti keripik dan produk kentang olahan berkontribusi besar pada asupan lemak. ${ }^{19}$ Penelitian longitudinal Racette et al pada orang dewasa menunjukan adanya peningkatan berat badan di akhir pekan sebesar $0.077 \mathrm{~kg}$. Meskipun kecil namun bisa berdampak pada kenaikan $4 \mathrm{~kg}$ dalam satu tahun jika pola peningkatan asupan di akhir pekan tetap berkelanjutan. ${ }^{12}$

Secara umum dengan semakin bertambahnya usia, konsumsi energi dari makanan akan mengalami penurunan. Dibandingkan dengan orang dewasa, terjadinya perubahan konsumsi makanan pada lansia sedikit dipengaruhi oleh adanya akhir pekan dan hari biasa. Pada lansia yang berusia 65 tahun keatas peningkatan asupan diakhir pekan lebih dipengaruhi oleh asupan lemak, dibandingkan zat gizi makro lainnya. ${ }^{19}$

Aktivitas fisik pada anak, remaja, dan orang dewasa menurun di akhir pekan. Hal ini mungkin disebabkan karena aktifitas fisik menjadi bagian dari kegiatan mata pelajaran atau pekerjaan yang rutin dilakukan di hari biasa. Selain itu saat akhir pekan lebih banyak waktu dihabiskan untuk kegiatan rekreasi dan menonton tv, dimana selama menonton tv sangat sedikit energi yang dikeluarkan ditambah lagi dengan konsumsi makanan yang tidak sehat dan berenergi tinggi sehingga mengakibatkan ketidak seimbangan energi yang akhirnya berdampak pada kegemukan. ${ }^{19}$ Pada hari biasa rata-rata waktu anak menonton TV 1.43 jam per hari dan meningkat 2 kali lipat di akhir pekan. ${ }^{21}$ Di hari biasa remaja laki-laki konsisten lebih banyak melakukan aktivitas fisik daripada sedentary lifestyle dibandingkan di akhir pekan. Sedangkan di akhir pekan remaja perempuan di hari minggu lebih banyak menghabiskan waktu untuk sedentary lifestyle dibandingkan hari sabtu. ${ }^{22}$ Pada orang dewasa tidak terdapat perbedaan aktifitas fisik antara hari biasa dan akhir pekan. Waktu tidur orang dewasa lebih lama di akhir pekan dibandingkan hari biasa, sehingga sedikit waktu yang digunakan untuk aktif beraktifitas. ${ }^{23}$

\section{Asupan energi di akhir pekan}

Karbohidrat, lemak, dan protein merupakan zat-zat gizi yang dapat menghasilkan energi. Energi dibutuhkan oleh tubuh untuk dapat melakukan aktivitas atau kegiatan sehari-hari. ${ }^{24}$ Hampir semua artikel memperlihatkan rata-rata asupan energi harian pada akhir pekan lebih besar dibandingkan hari biasa, dan peningkatan asupan kalori di akhir pekan dialami oleh semua kelompok usia. ${ }^{12,15,25-28,20}$ Hasil penelitian cross sectional Monteiro et al pada anak usia 10 tahun hingga orang dewasa menunjukkan adanya kenaikan rata-rata asupan energi di akhir pekan sebesar 8\% dibandingkan dengan hari biasa. ${ }^{25} \mathrm{Hal}$ tersebut juga didukung oleh peneitian Haines et al pada 28156 subyek usia 2 tahun hingga $\geq 70$ tahun, menyatakan rata-rata total asupan energi pada akhir pekan $82 \mathrm{kkal}$ lebih tinggi dibandingkan di hari biasa. ${ }^{28}$ Penelitian longitudinal Jahns et al dengan subjek wanita dewasa juga menujukkan hasil bahwa sebesar $75 \%$ subjek mengalami peningkatan asupan makan diakhir pekan dengan rata-rata energi saat akhir pekan 158 kalori lebih besar dibandingkan hari biasa. ${ }^{15}$

\section{Asupan karbohidrat di akhir pekan}

Karbohidrat merupakan sumber energi utama bagi tubuh. Jenis makanan yang merupakan sumber karbohidrat adalah padipadian, umbi-umbian, kacang-kacangan, dan gula. $^{24}$ Rata-rata asupan karbohidrat meningkat pada akhir pekan dibandingkan hari biasa. ${ }^{26,20}$ Penelitian longitudinal yang dilakukan Post et al pada anak SMA menunjukkan asupan karbohidrat pada akhir pekan pada siswa perempuan $12-15 \%$ lebih tinggi dan pada siswa laki-laki $7 \%$ lebih tinggi daripada hari biasa. Secara keseluruhan asupan karbohidrat siswa laki-laki meningkat dengan bertambahnya usia, sedangkan pada siswa perempuan cenderung menurun dengan usia. $^{20}$ 
Menurut penelitian cross-sectional Atmarita yang mengukur asupan gula, garam, dan lemak pada tingkat rumah tangga menunjukan, rata-rata konsumsi gula setiap orang sebesar 25.61 gram/orang/hari. Konsumsi gula meningkat dengan bertambahnya usia. ${ }^{29}$ Beberapa penelitian menunjukkan kontribusi gula tambahan pada asupan energi harian juga meningkat dibandingkan hari biasa. 25,27 Menurut penelitian cross sectional Monteiro et al ratarata asupan gula tambahan pada hari biasa sebesar $13 \%$ dan meningkat menjadi $15 \%$ pada hari libur. Selain itu juga terjadi peningkatan jumlah rata-rata konsumsi minuman manis, pasta, makanan manis, dan makanan penutup dengan gula tambahan pada akhir pekan. ${ }^{25}$

Berbeda dengan penelitian sebelumnya, peneitian Racette et al, Haines et al, dan Jahns et al yang mengklasifikasikan akhir pekan dimulai dari hari jumat hingga minggu menyatakan, asupan karbohidrat pada akhir pekan menurun dibandingkan hari biasa. ${ }^{12,15,28}$ Hasil yang berbeda dari ketiga penelitian tersebut dapat disebabkan karena karakteristik responden yang diteliti melibatkan kelompok usia dewasa dan dalam mengumpulkan data asupan makanan menggunakan metode recall 24 jam sebanyak lebih dari satu kali di hari biasa maupun diakhir pekan yang dilakukan pada musim berbeda.

\section{Asupan lemak di akhir pekan}

Lemak merupakan zat gizi yang memiliki fungsi utama sebagai sumber energi, alat angkut vitamin larut lemak, memelihara suhu tubuh, dan melindungi organ tubuh. ${ }^{24}$ Menurut penelitian cross-sectional Atmarita yang mengukur asupan gula, garam, dan lemak pada tingkat rumah tangga menunjukan, rata-rata asupan lemak total $53.3 \mathrm{gram} /$ kapita/hari. Asupan lemak cenderung lebih tinggi pada lakilaki dan penduduk perkotaan. Penduduk dengan kelas sosial atas 1.5 kali lebih banyak dibandingkan penduduk kelas sosial bawah. ${ }^{29}$ Dibandingkan karbohidrat dan protein, lemak menghasilkan kandungan kalori yang lebih besar, dan konsumsi lemak dalam jumlah tinggi berperan pada terjadinya obesitas pada semua golongan usia. $^{30}$ Hasil studi literatur membuktikan rata-rata asupan lemak pada akhir pekan meningkat dibandingkan hari biasa. ${ }^{12,25,26,28,20,21}$ Penelitian longitudinal Post et al pada remaja siswa SMA menyatakan ratarata asupan lemak di akhir pekan meningkat 7$15 \%$ pada siswa laki-laki dan $>20 \%$ pada siswa perempuan dibandingkan dengan hari biasa. ${ }^{20}$ Tidak hanya pada remaja, penelitian cross sectional Monteiro et al dengan subjek anak mulai usia 10 tahun sampai orang dewasa juga menunjukkan persentase asupan total lemak, lemak jenuh, dan lemak trans di akhir pekan lebih tinggi dibandingkan dengan hari biasa dengan rata-rata asupan lemak trans pada hari biasa meningkat lebih dari dua kali lipat di akhir pekan. ${ }^{25}$

\section{Asupan protein di akhir pekan}

Protein merupakan zat gizi yang memiliki fungsi penting dalam pertumbuhan dan pemeliharaan sel tubuh, pembentukan hormon, mangatur keseimbangan air, pembentukan antibody, mengangkut zat-zat gizi, dan sumber energi. ${ }^{24}$ Hasil studi literatur menunjukkan rata-rata asupan protein pada akhir pekan lebih besar dibandingkan hari biasa. ${ }^{26,20}$ Penelitian longitudinal Post et al menyatakan pada remaja perempuan asupan protein $10-15 \%$ lebih tinggi saat hari

libur dibandingkan hari sekolah. Sedangkan pada remaja laki-laki juga menunjukkan rata-rata asupan protein yang tinggi dihari libur, asupan protein dari hewani dua kali lipat lebih banyak dikonsumsi dibandingkan asupan protein dari sumber nabati. ${ }^{20}$

Berbeda dengan penelitian sebelumnya, penelitian Racette et al, Jahns et al, Rothausen et al, dan Haines et al menyatakan asupan protein di akhir pekan lebih rendah dibandingkan di hari biasa. ${ }^{12,15,27,28}$ Perbedaan hasil dari keempat penelitian tersebut dapat disebabkan karena pengambilan data asupan makan dilakukan menggunakan metode recall 24 jam sebanyak lebih dari satu kali di hari biasa maupun diakhir pekan yang dilakukan pada musim berbeda, serta jumlah sample yang digunakan bersekala ratusan dan ribuan.

\section{Asupan Makronutrient dengan Peningkatan Berat Badan}

Sebagian besar artikel yang digunakan menyatakan adanya peningkatan asupan energi dan zat gizi makronutrien saat akhir 
pekan dibandingkan hari biasa. Berdasarkan penelitian longitudinal Post et al selama 4 tahun dengan subjek kelompok usia remaja, rata-rata berat badan remaja putri yang berusia 12-17 tahun mengalami peningkatan dari $43 \mathrm{~kg}$ menjadi $58 \mathrm{~kg}$, dan pada remaja lakilaki dari $38 \mathrm{~kg}$ menjadi $74 \mathrm{~kg}$. Persentasi massa lemak pada remaja putri dari empat kali pengukuran skinfold juga mengalami peningkatan dari $23 \%$ menjadi $28 \%$ dan pada laki-laki dari $15 \%$ menjadi $17 \% .{ }^{20}$ Menurut penelitian longitudinal Jahns et al, asupan energi paling tinggi adalah saat hari sabtu dan paling rendah saat hari selasa, sedangkan asupan karbohidrat terendah pada hari jumat dibandingkan dengan hari senin, selasa atau rabu. ${ }^{15}$ Penelitian longitudinal Racette et al pada orang dewasa usia 50-60 tahun juga menunjukan adanya peningkatan total asupan energi dari $2021 \mathrm{kkal}$ di hari biasa menjadi 2257 kkal di akhir pekan. Selain itu juga terjadi peningkatan berat badan $0.077 \mathrm{~kg}$ per minggu, meskipun kecil namun bisa berdampak pada kenaikan $4 \mathrm{~kg}$ dalam satu tahun jika pola serupa berkelanjutan. ${ }^{12}$

Berdasarkan penelitian longitudinal yang dilakukan Gorin et al pada individu usia 18 tahun keatas dalam menjaga berat badan yang berhasil diturunkan sebanyak 30 pound selama 1 tahun, menyatakan individu yang memiliki diet konsisten antara hari biasa dengan akhir pekan 1.5 kali lebih dapat mempertahankan berat badannya. Sedangkan orang dengan diet yang tidak konsisten antara dihari biasa dan akhir pekan lebih cenderung mengalami peningkatan berat badan selama setahun berikutnya. ${ }^{31}$

Menurut studi literature McCarty, Asupan orang dewasa di Amerika signifikan meningkat di akhir pekan. Dalam beberapa kasus peningkatan asupan energi melebihi 100 kkal setiap hari di akhir pekan dengan asupan lemak dan alkohol sebagai kontributor terbesar. Selain itu di akhir pekan orang dewasa lebih sering mengkonsumsi makanan dengan porsi besar. Peningkatan asupan energi yang konsisten setiap hari libur signifikan berdampak pada perubahan berat badan selama satu tahun. Peningkatan 100 kkal setiap akhir pekan selama setahun menyebabkan peningkatan berat badan $2 \mathrm{~kg}$ sehingga berkontribusi pada peningkatan prevalensi overweight dan obesitas. ${ }^{19}$

Tabel 1. Bebarapa Artikel Penelitian Terkait Asupan Makan Di Akhir Pekan Terangkum Dalam Daftar Jurnal Rujukan

\begin{tabular}{|c|c|c|c|c|}
\hline Peneliti & Metode & Popolasi & Pengukuran & Hasil \\
\hline $\begin{array}{l}\text { Monteiro, et } \\
\text { al. }\end{array}$ & $\begin{array}{l}\text { Cross- } \\
\text { sectional }\end{array}$ & $\begin{array}{l}34.003 \\
\text { subyek usia } \\
10 \text { sampai } \\
\geq 60 \text { tahun. }\end{array}$ & $\begin{array}{l}\text { Food record } 2 x \\
\text { dalam satu } \\
\text { minggu. }\end{array}$ & 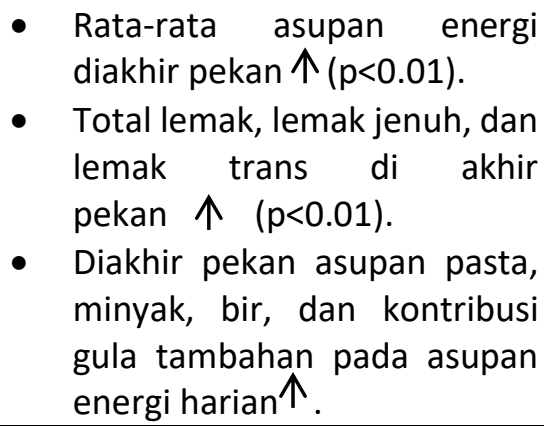 \\
\hline
\end{tabular}

\begin{tabular}{|c|c|c|c|c|}
\hline Vassilopoulou, & Case control & 51 anak & Food recall yang & Total asupan energi, \\
\hline et al. & & $\begin{array}{l}\text { usia } 6-11 \\
\text { tahun. }\end{array}$ & $\begin{array}{l}\text { dilakukan } 1 \mathrm{x} \\
\text { dihari biasa dan } \\
1 \mathrm{x} \text { diakhir } \\
\text { pekan. }\end{array}$ & $\begin{array}{l}\text { karbohidrat, lemak dan } \\
\text { protein pada kelompok anak } \\
\text { alergi dan anak sehat di akhir } \\
\text { pekan } \uparrow \text {. }\end{array}$ \\
\hline $\begin{array}{l}\text { Rothausen, et } \\
\text { al. }\end{array}$ & $\begin{array}{l}\text { Cross- } \\
\text { sectional }\end{array}$ & $\begin{array}{l}784 \text { subyek } \\
\text { usia } 4-14 \\
\text { tahun. }\end{array}$ & $\begin{array}{lr}\text { Food } & \text { record } \\
\text { selama } 7 & \text { hari } \\
\text { dalam } & \\
\text { seminggu. } & \end{array}$ & $\begin{array}{l}\text { Asupan energi di akhir } \\
\text { pekan } \uparrow(p<0.05) \text {. } \\
\text { Pada akhir pekan asupan } \\
\text { energi dari gula tambahan } \uparrow, \\
\text { seperti makanan dan }\end{array}$ \\
\hline
\end{tabular}




\begin{tabular}{|c|c|c|c|c|}
\hline & & & & $\begin{array}{l}\text { minuman manis serta coklat, } \\
\text { sedangkan asupan serat , } \\
\text { buah dan sayur } \downarrow \text {. } \\
\text { Prevalensi subjek obes pada } \\
\text { usia 7-10 tahun hampir sama } \\
\text { antara anak perempuan dan } \\
\text { laki-laki. Tapi pada kelompok } \\
\text { usia 4-6 tahun anak } \\
\text { perempuan lebih banyak yang } \\
\text { mengalami obes. } \\
\text { kualitas diet berbeda } \\
\text { signifikan saat hari libur dan } \\
\text { hari biasa. biasa } \\
\text { Dibandingkan hari dari } \\
\text { energi yang berasal d } \\
\text { protein lebih } \downarrow \text {. }\end{array}$ \\
\hline Hart, et al. & $\begin{array}{l}\text { Cross- } \\
\text { sectional }\end{array}$ & $\begin{array}{lr}81 & \text { anak } \\
\text { usia } & 6-9 \\
\text { tahun. } & \end{array}$ & $\begin{array}{l}\text { Food recall } 2 \mathrm{x} \\
\text { dihari biasa dan } \\
1 \mathrm{x} \text { diakhir } \\
\text { pekan. }\end{array}$ & 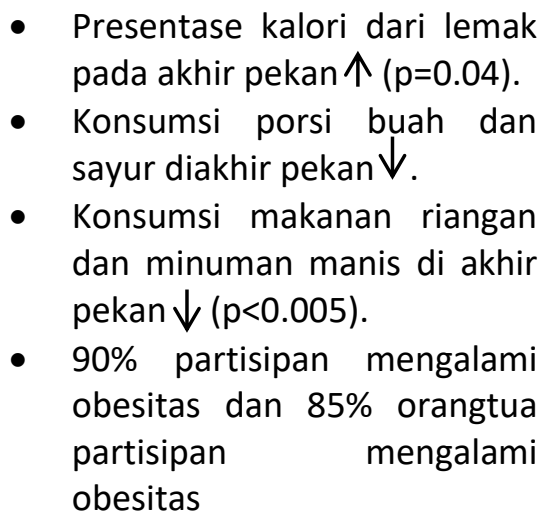 \\
\hline Haines, et al. & $\begin{array}{l}\text { Cross- } \\
\text { sectional }\end{array}$ & $\begin{array}{l}28.156 \\
\text { sampel usia } \\
2 \quad-\quad \geq 70 \\
\text { tahun. }\end{array}$ & $\begin{array}{lr}\text { Food recall yang } \\
\text { dilakukan } & 2 \mathrm{x} \\
\text { diakhir } & \text { pekan } \\
\text { dan } 2 x & \text { dihari } \\
\text { biasa } & \text { pada } \\
\text { musim } & \text { yang } \\
\text { berbeda. } & \end{array}$ & 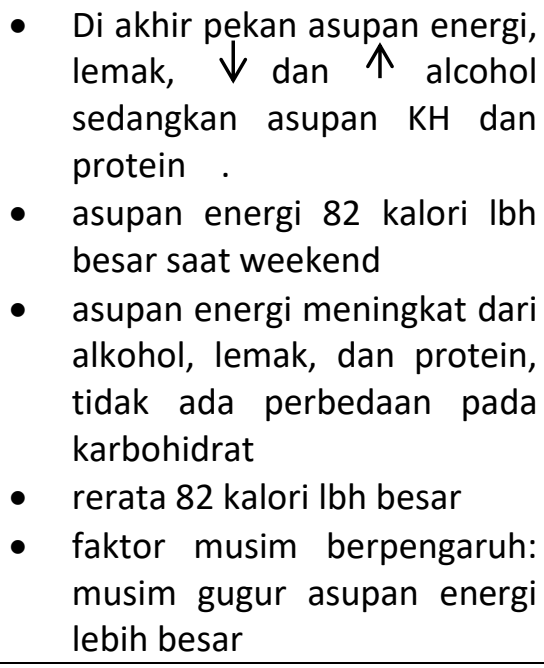 \\
\hline Post, et al. & Longitudinal & $\begin{array}{l}600 \text { siswa } \\
\text { SMA usia } \\
12-17 \\
\text { tahun. }\end{array}$ & $\begin{array}{l}\text { FFQ yang } \\
\text { dibedakan } \\
\text { antara akhir } \\
\text { pekan dan hari } \\
\text { biasa. }\end{array}$ & $\begin{array}{l}\text { - Di akhir pekan asupan energi, } \\
\text { protein, lemak, dan } \\
\text { karbohidrat pada remaja laki- } \\
\text { laki dan perempuan } \uparrow \text {. } \\
\text { Rata-rata berat badan remaja } \\
\text { putri yang berusia } 12-17 \\
\text { tahun dan pada remaja laki- } \\
\text { laki } \uparrow \text {. } \\
\text { Persentasi lemak pada remaja } \\
\text { putri dan pada laki-laki . }\end{array}$ \\
\hline
\end{tabular}




\begin{tabular}{|c|c|c|c|c|}
\hline Racette et al & Longitudinal & $\begin{array}{l}48 \text { orang } \\
\text { usia } 50-60 \\
\text { tahun. }\end{array}$ & $\begin{array}{l}\text { Food recall } 24 \bullet \\
\text { jam selama } 7 \\
\text { hari setiap } 3 \bullet \\
\text { bulan. } \\
\end{array}$ & 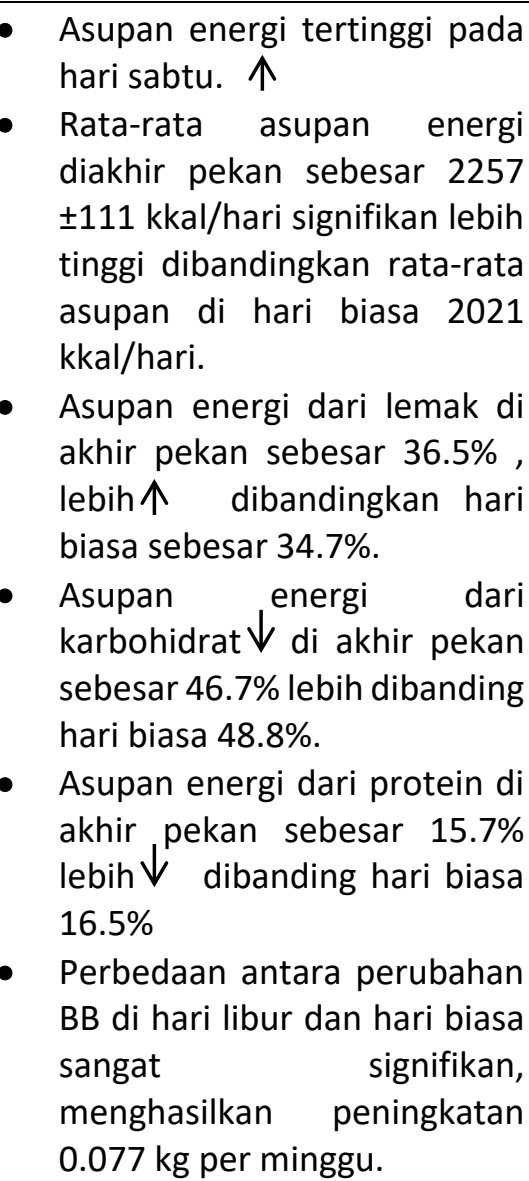 \\
\hline Jahns, et al. & Longitudinal & $\begin{array}{l}52 \text { ibu } \\
\text { rumah } \\
\text { tangga usia } \\
18-35 \text { dan } \\
40-60 \\
\text { tahun. }\end{array}$ & $\begin{array}{l}\text { Food recall } 24 \\
\text { jam setiap } 10 \\
\text { hari sekali dalam } \\
\text { setahun. } \\
\bullet\end{array}$ & 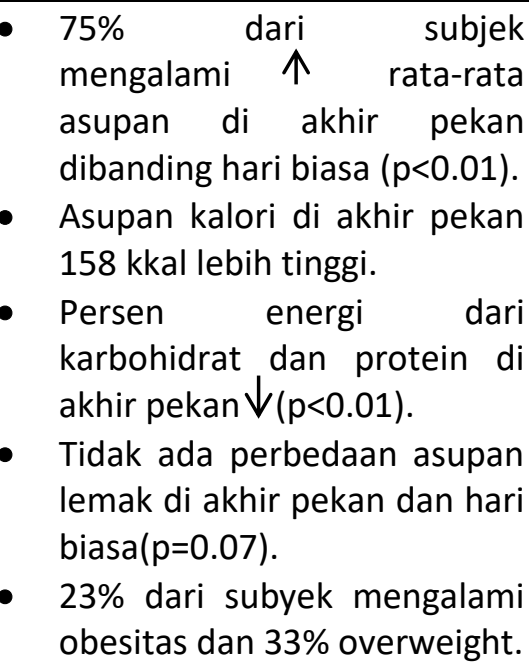 \\
\hline
\end{tabular}

\section{KESIMPULAN}

Sebagian besar hasil penelitian menunjukkan bahwa asupan energi dan zat gizi makro di akhir pekan lebih tinggi dibandingkan dengan hari biasa. Konsumsi unhealthy food di akhir pekan seperti makanan dan minuman dengan kandungan tinggi gula, tinggi lemak, dan alkohol tampaknya menyebabkan peningkatan kalori.
Pada remaja dan orang dewasa peningkatan asupan energi dan zat gizi makro di akhir pekan berdampak pada peningkatan berat badan dan persen lemak tubuh sehingga berkontribusi pada peningkatan prevalensi overweight dan obesitas. Diperlukan upaya pencegahan obesitas melalui promosi kesehatan masyarakat dengan memperhatikan asupan makanan saat akhir pekan baik dari segi kuantitas maupun kualitasnya. 


\section{ACKNOWLEDGEMENT}

Penulis mengucapkan terima kasih kepada dosen Departemen Gizi FKM UNAIR atas bimbingan dan saran yang diberikan sehingga penulisan literatur review ini dapat terselesaikan.

\section{REFERENSI}

1. World Health Organization. Obesity. Obesity (2014). Available at: http://www.wpro.who.int/mediacentre /factsheets/ obesity/en/. (Accessed: 26th March 2018)

2. Ogden, C. L., Carroll, M. D., Cheryl, D. F. \& Flegal, K. M. Prevalence of Obesity Among Adults and Youth : United States, 2011-2014. 2011-2014 (2015). doi:10.1017/S1368980017000088

3. Hales, C. M., Carroll, M. D., Fryar, C. D. \& Ogden, C. L. Prevalence of Obesity Among Adults and Youth: United States, 2015-2016. NCHS Data Brief 288, 1-8 (2017).

4. RI, D. Riset kesehatan dasar 2007. depkes RI 1-50 (2007). doi:10.3406/arch.1977.1322

5. RI, D. Riset kesehatan dasar 2013. depkes RI (2013).

6. Weinberger, N. A., Kersting, A., RiedelHeller, S. G. \& Luck-Sikorski, C. Body Dissatisfaction in Individuals with Obesity Compared to Normal-Weight Individuals: A Systematic Review and Meta-Analysis. Obes. Facts 9, 424-441 (2017).

7. Sangun, Ö. et al. Prevalence of Metabolic Syndrome in Obese Children and Adolescents using Three Different Criteria and Evaluation of Risk Factors Original Article. J. Clin. Res. Pediatr. Endocrinol. 3, 70-76 (2011).

8. Nemiary, D., Shim, R., Mattox, G. \& Holden, K. The Relationship Between Obesity and Depression Among Adolescents. Psychiatr Ann 42, 305-308 (2013).

9. Kim, J. \& So, W. Association Between Overweight / Obesity and Academic Performance in South Korean Adolescents. 21, 179-183 (2013).
10. Indrasari, R. \& Kurniati, Y. Literature review: perubahan gaya hidup sebagai upaya manajemen sindroma metabolik pada remaja. 40, 9-20 (2017).

11. Hill O., J. NIH Public Access. Circulation 126, 126-132 (2012).

12. Racette, S. B. et al. Influence of weekend lifestyle patterns on body weight. Obesity 16, 1826-1830 (2008).

13. Orsama, A. L. et al. Weight rhythms: Weight increases during weekends and decreases during weekdays. Obes. Facts 7, 36-47 (2014).

14. Resita, R. Perilaku hedonisme remaja di Mall Panakukkang Makasar. (Universitas Islam Negeri Alauddin Makasar, 2016).

15. Jahns, L. et al. Diet Quality Is Lower and Energy Intake Is Higher on Weekends Compared with Weekdays in Midlife Women: A 1-Year Cohort Study. J. Acad. Nutr. Diet. 117, 1080-1086.e1 (2017).

16. Mahan, L. K. \& Raymond, J. L. Krause's Food \& the Nutrition Care Process. Food and Nutrition Board, Institute of Medicine, National Academies (2017). doi:10.1111/j.17534887.2004.tb00011.x

17. Ayala, G., Rogers, M. \& Arredondo, E. Away From Home Food Intake and Risk for Obesity: Examining the Influence of Context. ... 16, 1002-1008 (2008).

18. At, A. \& NJ, C. Factors predisposing to obesity : a review of the literature. 14, 81-84 (2009).

19. Mccarthy, S. Physiology \& Behavior Weekly patterns, diet quality and energy balance. Physiol. Behav. 1-5 (2014). doi:10.1016/j.physbeh.2014.02.046

20. Post, B., Kemper, H. C. \& Storm-Van Essen, L. Longitudinal changes in nutritional habits of teenagers: differences in intake between schooldays and weekend days. Br. J. Nutr. 57, 161-176 (1987).

21. Hart, C. N., Raynor, H. A., Osterholt, K. M., Jelalian, E. \& Wing, R. R. Eating and Activity Habits of Overweight Children on Weekdays and Weekends. 6, 467472 (2011).

22. Collings, P. J. et al. Levels and patterns of objectively-measured physical activity volume and intensity distribution in UK 
adolescents: The ROOTS study. Int. J. Behav. Nutr. Phys. Act. 11, 1-12 (2014).

23. Drenowatz, C. et al. The Association of Physical Activity during Weekdays and Weekend with Body Composition in Young Adults. J. Obes. 2016, (2016).

24. Almatsier, S. Prinsip Dasar Ilmu Gizi. (PT Gramedia Pustaka Utama, 2009).

25. Monteiro, L. S. et al. Food Consumption According to the Days of the Week National Food Survey, 2008-2009. Rev. Saude Publica 51, 93 (2017).

26. Vassilopoulou, E., Christoforou, C., Andreou, E. \& Heraclides, A. Effects of food allergy on the dietary habits and intake of primary schools' cypriot children. Eur. Ann. Allergy Clin. Immunol. 49, 181-185 (2017).

27. Rothausen, B. W. et al. Differences in Danish children's diet quality on weekdays v. weekend days. Public Health Nutr. 15, 1653-1660 (2012).

28. Haines, P. S., Hama, M. Y., Guilkey, D. K. \& Popkin, B. M. Weekend eating in the United States is linked with greater energy, fat, and alcohol intake. Obes. Res. 11, 945-949 (2003).

29. Atmarita, Jahari, A. B., Sudikno \& Soekatri, M. Asupan gula, garam, dan lemak di Indonesia: Analisis Survei Konsumsi Makanan Individu (SKMI) 2014. Persagi 39, 1-14 (2016).

30. Madsen, L., Liaset, B. \& Kristiansen, K. Macronutrients and obesity: Views, news and reviews. Future Lipidol. 3, 4374 (2008).

31. Gorin, A. A., Phelan, S., Wing, R. R. \& Hill, J. O. Promoting long-term weight control: Does dieting consistency matter? Int. J. Obes. 28, 278-281 (2004). 